\title{
都市型廃棄物を原料として製造された セメント硬化体の細孔溶液組成
}

\author{
河合研至 $^{1} \cdot$ 松本健一 $^{2} \cdot$ 田澤榮 $^{3} \cdot$ 横山滋 $^{4}$ \\ ${ }^{1}$ 正会員 工博 広島大学助教授 大学院工学研究科社会環境システム専攻（テ7398527 広島県東広島市鏡山一丁目41） \\ E-mail:kkawai@hiroshima-u.ac.jp \\ 2学生会員 広島大学大学院生 大学院工学研究科構造工学専攻 (下739-8527 広島県東広島市鏡山一丁目 4-1) \\ 3フェロー会員 工博 広島大学名誉教授（干739-8527 広島県東広島市鏡山一丁目 4-1） \\ ${ }^{4}$ 工修 太平洋セメント株式会社 研究本部（勇285-8655 千葉県佐倉市大作二丁目 4-2）
}

\begin{abstract}
原料の約 50\%に都市型廃衰物を利用して製造されたセメントは，普通ポルトランドセメントと比較して，C3A と 塩素力概して多く含まれる．塩素が多いことから，鉄筋コンクリートに適用した場合には，鉄筋腐食を引き起こす ことか漅念されている. 本研究では，セメント硬化体に含まれる細孔溶液に着目し，細孔溶液の組成ならびにその 経時変化の観点から鉄筋腐食の可能性について検討を行った，その結果，都市型廃棄物を原料として製造されるセ メントでは，細孔溶液中の塩化物イオン濃度か潽通ポルトランドセメントの場合と比較して高くなるものの塩化物 イオン濃度と水酸化物イオン濃度の比は低く，鉄筇か腐食する指標とされる値は大きく下回ることが明らかになっ た. これらより，鉄筋腐食の可能性に関しては，普通ポルトランドセメントと同様に考えてもよいと考えられる.
\end{abstract}

Key Words : eco-cement, municipal solid wastes, pore solution, chloride content, calcium aluminate content

\section{1.はじめに}

環境負荷低減への意識の高まりから，セメント・コン クリート分野においても完全リサイクルコンクリートの 提唱 ${ }^{1)}$ やコンクリートがらの再利用 ${ }^{2)}$, セメント製品用骨 材としてのガラスカレットの利用 ${ }^{3)}$ など，資源の有効利 用に向けた取組みが数多くなされ始めている ${ }^{4)}$.

セメントの製造においては，焼成用燃料としての廃夕 イヤ，廃パチンコ台の利用 5やセメント原料としての下

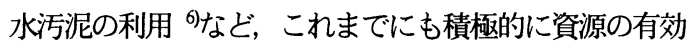
利用が試みられ実用化している. さらに平成 5 年 8 年 に実施された経済産業省 (当時, 通商産業省) の「生活 産業廃棄物等高度処理 - 有効利用技術研究開発事業」に おける 1 テーマとして,「都市型総合廃棄物利用エコセ メント生産技術」が実証研究され ，都市ごみ焼却灰や 下水污泥を原料としたセメントの製造が開発された ${ }^{8), 9)}$.

このセメントでは, 都市ごみ焼却灰や生石灰混合処理 した脱水污泥ケーキなどの廃棄物を当初は原料の約 $60 \%$
に使用し, 焼成温度が $1000 \sim 1300^{\circ} \mathrm{C}$ と低く燃料消費量や $\mathrm{CO}_{2}$ 発生量が少ないことから, 環境負荷低減に寄与する 画期的なセメントとして注目されるに至った.

開発過程の中で原料とする廃棄物の最適な配分等か検 討され，現在では原料中における廃棄物の利用割合か的 50\%となり，そのほとんどを都市ごみ焼却灰から供給す るに至っているが, 都市ごみ焼却灰は通常 16〜25\%のア ルミナと 5～10\%の塩素を含有することから，このセメ ントの特徵は, カルシウムアルミネート系の鉱物と塩素 を多量に含有することにある. そのため, 開発当初のセ メントでは, 塩素含有量が 1\%程度にまで達する場合が あり，鉄笳の発錆か渻念され用途は無筋コンクリートに 限定されると考えられていた.

それ以降，セメント製造工程における効率的な塩素除 去の開発が進められ，塩素バイパスシステムにより塩素 含有量が普通ポルトランドセメントの JIS 規格を満足す る程度にまで低減することが可能となった ${ }^{10)}$.これらの 製造技術の開発亡並行して，廃棄物の有効利用技術の一 
表-1 使用したセメントの物理的特性および化学的特性

\begin{tabular}{|c|c|c|c|c|c|c|c|c|c|c|}
\hline & \multirow{2}{*}{\multicolumn{2}{|c|}{$\begin{array}{c}\begin{array}{c}\text { 密度 } \\
\left(\mathrm{g} / \mathrm{cm}^{3}\right)\end{array} \\
\end{array}$}} & \multirow{2}{*}{ 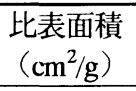 } & \multicolumn{7}{|c|}{ 鉱物組成（\%） } \\
\hline & & & & $\mathrm{C}_{3} \mathrm{~S}$ & \multicolumn{2}{|r|}{$\mathrm{C}_{2} \mathrm{~S}$} & $\mathrm{C}_{3} \mathrm{~A}$ & \multicolumn{2}{|c|}{$\mathrm{C}_{11} \mathrm{~A}_{7} \cdot \mathrm{CaCl}_{2}$} & $\mathrm{C}_{4} \mathrm{AF}$ \\
\hline EC200 & \multirow{2}{*}{\multicolumn{2}{|c|}{$\begin{array}{l}3.13 \\
3.13\end{array}$}} & 4,300 & 51.9 & \multicolumn{2}{|r|}{22.2} & 18.5 & \multicolumn{2}{|l|}{0.5} & 6.9 \\
\hline EC400 & & & 4,300 & 53.1 & \multirow{2}{*}{\multicolumn{2}{|c|}{$\begin{array}{r}19.0 \\
9.6\end{array}$}} & 20.3 & \multicolumn{2}{|l|}{0.9} & 6.6 \\
\hline EC540 & \multicolumn{2}{|c|}{3.16} & 4,660 & 52.2 & & & 13.3 & \multirow{2}{*}{\multicolumn{2}{|c|}{---}} & 13.7 \\
\hline EC700 & \multicolumn{2}{|c|}{3.16} & 4,300 & 53.6 & \multicolumn{2}{|r|}{20.4} & 17.8 & & & 6.3 \\
\hline EC5000 & \multicolumn{2}{|c|}{3.13} & 4,300 & 68.1 & \multicolumn{2}{|r|}{4.5} & --- & \multicolumn{2}{|l|}{24.1} & 3.3 \\
\hline EC8000 & \multicolumn{2}{|c|}{3.13} & 4,300 & & & & & & & \\
\hline $\mathrm{NC} 1$ & & & 3,220 & 50.2 & \multicolumn{2}{|r|}{24.4} & 8.5 & \multicolumn{2}{|l|}{--.- } & 9.4 \\
\hline $\mathrm{NC2}$ & \multicolumn{2}{|c|}{3.16} & 3,280 & 56.2 & \multicolumn{2}{|r|}{24.3} & 9.6 & \multicolumn{2}{|l|}{-.-- } & 10.0 \\
\hline $\mathrm{NC} 3$ & \multicolumn{2}{|c|}{3.15} & 3,440 & 62.5 & \multicolumn{2}{|r|}{12.5} & 8.4 & $-\cdots$ & & 8.9 \\
\hline & & & & & 化学紝 & 成 $(\%)$ & & & & \\
\hline & $\mathrm{SiO}_{2}$ & $\mathrm{Al}_{2} \mathrm{O}_{3}$ & $\mathrm{Fe}_{2} \mathrm{O}_{3}$ & $\mathrm{CaO}$ & $\mathrm{MgO}$ & $\mathrm{SO}_{3}$ & $\mathrm{Na}_{2} \mathrm{O}$ & $\mathrm{K}_{2} \mathrm{O}$ & $\mathrm{R}_{2} \mathrm{O}$ & $\mathrm{Cl}$ \\
\hline EC200 & 18.8 & 8.3 & 1.9 & 63.1 & 1.4 & 4.5 & & & 0.05 & 0.02 \\
\hline EC400 & 19.1 & 8.1 & 2.0 & 62.7 & 1.4 & 4.5 & & & 0.05 & 0.04 \\
\hline EC540 & 17.1 & 7.9 & 4.4 & 61.4 & 1.8 & 3.7 & 0.24 & 0.02 & 0.25 & 0.054 \\
\hline EC700 & 18.9 & 8.1 & 1.9 & 62.8 & 1.5 & 4.5 & & & 0.04 & 0.07 \\
\hline EC5000 & 15.4 & 10.0 & 2.5 & 58.7 & 1.7 & 7.2 & 0.7 & 0.01 & 0.71 & 0.5 \\
\hline EC8000 & 15.0 & 10.5 & 2.6 & 56.7 & 1.7 & 9.2 & & & 0.78 & 0.8 \\
\hline $\mathrm{NC1}$ & 21.7 & 5.2 & 3.1 & 64.0 & 1.0 & 2.2 & 0.37 & 0.39 & 0.63 & 0.005 \\
\hline $\mathrm{NC} 2$ & 22.0 & 5.4 & 3.1 & 64.1 & 1.3 & 2.1 & & & 0.63 & 0.003 \\
\hline NC3 & 20.8 & 5.0 & 2.9 & 64.9 & 1.2 & 2.0 & & & 0.64 & 0.003 \\
\hline
\end{tabular}

$\left({ }^{*}\right)$ EC8000 の鈗物組成は，EC5000に近いものであるが分析が行われておらず明らかでない. また, $\mathrm{Na}_{2} \mathrm{O}, \mathrm{K}_{2} \mathrm{O}$ の 項が空白のセメントに関しては， $\mathrm{R}_{2} \mathrm{O}$ の値のみ明らかとなっており，それぞれの分析値は不明．なお，Cl関 しては分析方法の相違により測定精度が異なっている.

つとしての位置付けを確たるものとするため，この種の セメントの規格化か強く要望され，2000年には標準情報 （TR）としての制定が行われた ${ }^{11}$. 現状では，0.05\%付 近を目標塩素含有量としたセメントの製造が中心となっ ている.

本研究では，普通ポルトランドセメントと比較して塩 素含有量が高く，また鉱物組成ならびにその構成此率の 異なる，都市型廃棄物を原料として製造されたセメント について塩素含有量の異なる数種のセメントを使用し, セメント硬化体に含まれる細孔溶液に着目し, 細孔溶液 の組成ならびにその経時変化の観点から主に鉄筋腐食の 可能性について検討を行った.

\section{2. 実験概要}

\section{（1）使用材料}

セメントには，都市型廃棄物を原料として製造された セメント（以下，EC）6種類ならびに普通ポルトランド セメント（以下，NC）3 種類を使用した．それぞれの EC は塩素含有量が異なる.ここでは便宜上，塩素含有

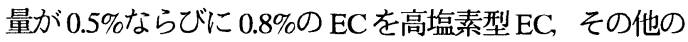
$\mathrm{EC}$ を低塩素型 $\mathrm{EC}$ と呼ぶこととする. 使用したセメント
の物理的特性および化学的特性を表-1 に示す. なお, $\mathrm{W} / \mathrm{C}=0.35$ の供試体については高性能减水剤としてポリ カルボン酸塩系を, セメントとして EC5000 または EC8000 を使用した供試体では高性能减水剂としてリグ ニンスルホン酸塩系, 凝結遅延剂としてクエン酸を使用 した.

\section{（2）供試体の種類と養生方法}

供試体はすべてセメントペーストとし, 水セメント比 は $0.35 ， 0.40 ， 0.50$ の 3 種類とした. ミキサーを用いて セメントペーストを練り混ぜた後, 若材龄用の試料はバ ットに受けてラップフィルムで覆い, 細孔溶液の抽出ま で $20^{\circ} \mathrm{C}$ 環境下で静置した. なお, 抽出時には予めハン ドスコップを用いて練り返しを行った，それ以外の抽出 用試料は $\phi 50 \times 100 \mathrm{~mm}$ の型枠に打設後, 上面をパラフィ ン製フィルムで覆い密封し, 抽出材齢に達するまで $20^{\circ} \mathrm{C}$ の環境下で保存した.

\section{（3）細孔溶液の抽出方法}

細孔溶液の抽出は，材齡 6 時間までは遠心分離，それ 以降は高圧抽出により行った. 高圧抽出においては，基 本的に供試体 1 体から細孔溶液を抽出したが, 抽出量が 極めて少ない場合には供試体 2 体について抽出を行い 


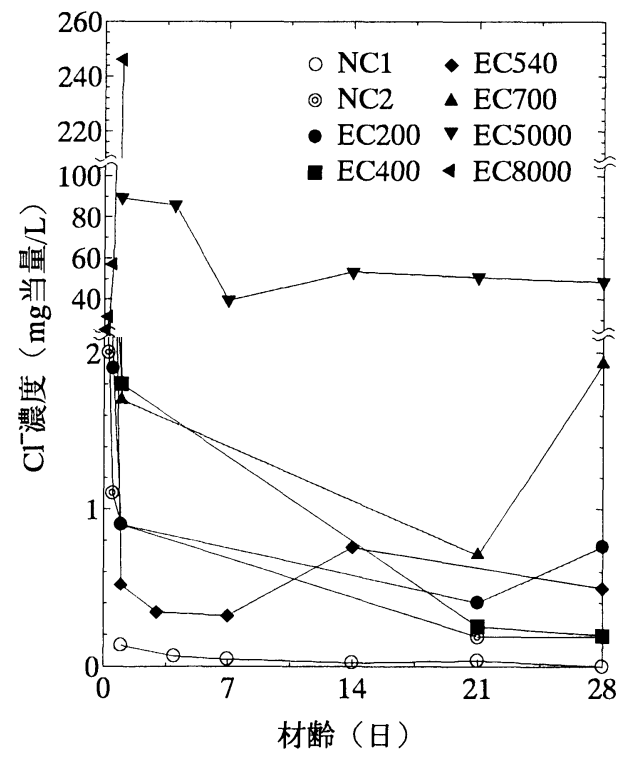

図-1 細孔溶液中の Cl-濃度の経時変化

両者の抽出液を混合して細孔溶液とした. ただし， EC8000 を用いたセメントペーストの細孔溶液抽出は, 材齢 1 日までである.

遠心分離では，セメントペーストを適当量だけ容器に とった後遠心分離機に取り付け，3,000rpm で 10 分間の 回転を行った. 遠心分離を行った容器の上澄み液を吸引 ろ過し分析に供した.

高圧抽出では, Longuet et $\mathrm{al}^{12)}$ によって考案され Bameyback and Diamond ${ }^{13}$ によって改良された細孔溶液 抽出装置を用いて，最大で約 $500 \mathrm{~N} / \mathrm{mm}^{2}$ までの加圧と除 荷を繰り返しながら供試体中の細孔溶液を抽出した後, 溶液については吸引ろ過を行い分析に供した.

\section{（4）細孔溶液の分析方法}

細孔溶液抽出後, 直ちにフェノールフタレインを指示 薬として塩酸による中和滴定を行い, 溶液の $\mathrm{OH}$ 濃度を 定量した. 残りの溶液について, 適当な倍率で希釈を行 った後, $\mathrm{Na}^{+}$濃度, $\mathrm{K}^{+}$濃度は原子吸光光度法, $\mathrm{Ca}^{2+}$ 濃度は フレーム光度法, $\mathrm{Cl}$ 濃度, $\mathrm{SO}_{4}{ }^{2}$ 濃度はイオンクロマトグ ラフィーにより定量を行った.

\section{3. 実験結果および考察}

\section{（1）細孔溶液中の塩素の挙動}

$\mathrm{W} / \mathrm{C}=0.50$ で作製した供試体について，細孔溶液中の $\mathrm{Cl}$ 濃度の経時変化を図-1に, 材龄 1 日までの結果を拡大 したものを図-2に示す.

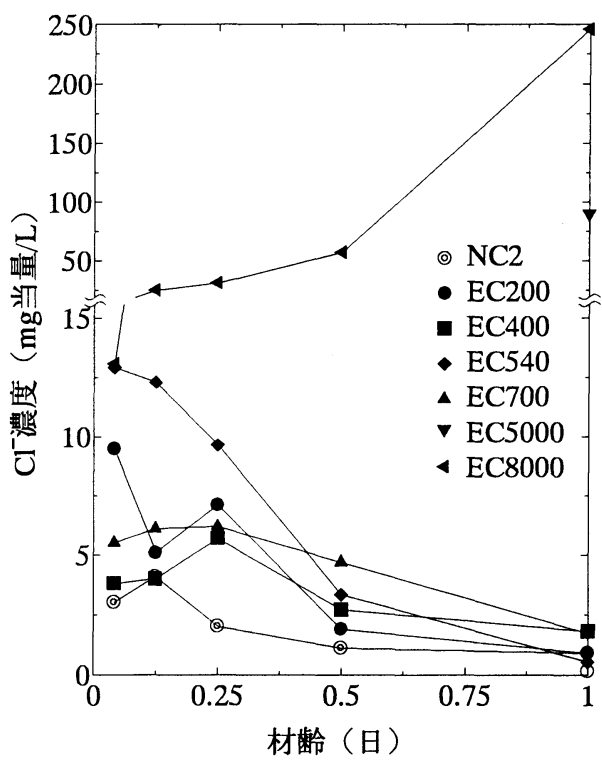

図-2 細孔溶液中の Cl-濃度の経時変化（材齢 1 日まで）

表-2 EC5000 と NC1 の細孔溶液抽出量の比較

\begin{tabular}{cccc}
\hline \multirow{2}{*}{\begin{tabular}{c} 
材 $\begin{array}{c}\text { 龄 } \\
\text { (日) }\end{array}$ \\
\cline { 2 - 3 }
\end{tabular}} & \multicolumn{3}{c}{ 抽出量 $(\mathrm{g})$} \\
\cline { 2 - 3 } & EC5000 & NC1 \\
\hline 1 & 37.4 & 28.5 & 48.1 \\
\hline 4 & 3.79 & 1.54 & 18.5 \\
\hline 7 & 4.70 & 1.80 & 15.1 \\
\hline 14 & 3.04 & 0.414 & 13.0 \\
\hline 21 & 0.211 & 0.624 & 5.06 \\
\hline 28 & 0.333 & 0 & 10.9 \\
\hline
\end{tabular}

EC8000 における初期の細孔溶液中の Cr濃度は非常に 高い，混練後 1 時間から材龄 1 日までは濃度か增加し続 け, 材龄 1 日では $246 \mathrm{mg}$ 当量しに達する. 一方, 低塩素 型 $\mathrm{EC}$ ならびに NC では混練直後から細孔溶液中の $\mathrm{Cl}^{-}$ 濃度が咸少している. セメント中のカルシウムアルミネ 一ト系鉱物の形態の相違により, 塩素の挙動が異なるこ とがわかる. すなわち, 主にC $\mathrm{C}_{3} \mathrm{~A}$ としてアルミネート相 か存在するセメントでは, 細孔溶液中に溶出したCが直 ちに $\mathrm{C}_{3} \mathrm{~A}$ と反応を開始しフリーデル氏塩を形成し始める のに対し, カルシウムアルミネート相が $\mathrm{C}_{11} \mathrm{~A}_{7} \cdot \mathrm{CaCl}_{2}$ で 構成されているセメントでは, Cヤの溶出が先行しフリー デ氏塩が形成されていないことが推察される.

また，図-1に示すように，EC5000においても NCや 低塩素型 $\mathrm{EC}$ と比較して, 材路 1 日以降の細孔溶液中の C「濃度が非常に高い值で推移している. ただし，表-2 に示すように ${ }^{14)}$, EC5000 では NC と比較して細孔溶液 


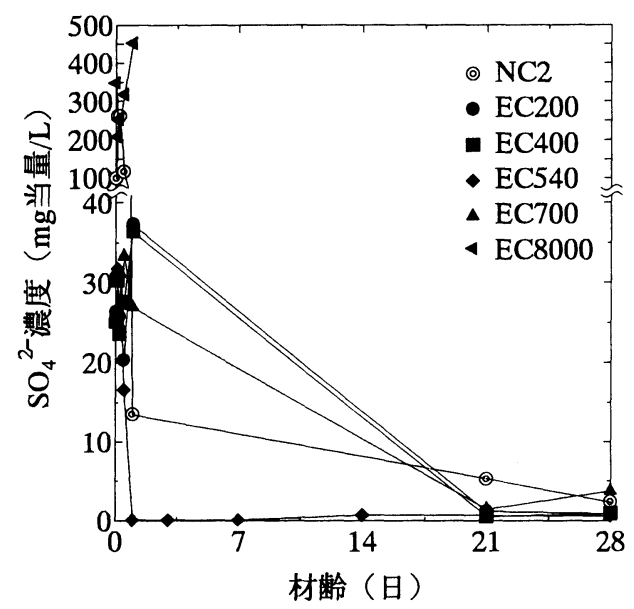

図-3 細孔溶液中の $\mathrm{SO}_{4}{ }^{2-}$ 濃度の経時変化

の抽出量が極めて少ない. 材齢 28 日においては, 2 体の うち1体に関してはまったく抽出することができなかっ た. EC5000 はカルシウムアルミネート相としてカルシ ウムクロロアルミネートを主成分としていることから, $\mathrm{NC}$ や低塩素型EC と比較して, 水和反応加非常に速やか に進行し, 密封養生で外部からの水分の供給がないため, 内部において自己乾燥状態か形成されていることが考え られる.このことは細孔溶液の連続性が保たれにくいこ とを示しており, 細孔溶液を介して塩化物イオンや電子, 溶存酸素の移動が生じにくくなっている. したがって, Cl濃度が高い值であっても鉄筋の腐食は進行しにくい 状態となっていると言える ${ }^{15)}$.

低塩素型 EC に関しては，Cl濃度が材齢初期から徐々 に隇少しており, 内部でフリーデ氏塩としての固定が 進行していることがうかがえる. また，細孔溶液中にお ける濃度はNC と比較して高くなっているが, EC の塩素 含有量がNCの 4倍〜20倍程度であることを勘案したと き，低い値で推移していると言える．このことは，EC の $\mathrm{C}_{3} \mathrm{~A}$ 含有量か高いこともあわせて考えたとき， ECに おいてフリーデル氏塩として固定可能な塩素量が NCよ りも多くなっていることか推察される. なお, 図-1にみ られるように, 細孔溶液中のC7濃度は低塩素型 EC の塩 素含有量に比例して増加していない. 材㱓28日において EC200 やEC700において比較的高い值を示している. こ れは, EC200およびEC700が他の低塩素型EC と比較し て若干カルシウムアルミネート相が少なくなっているこ となどがフリーデル氏塩としての固定に影響しているた めと思われるが, 本研究の範囲では詳細を明らかとする ことはできなかった.

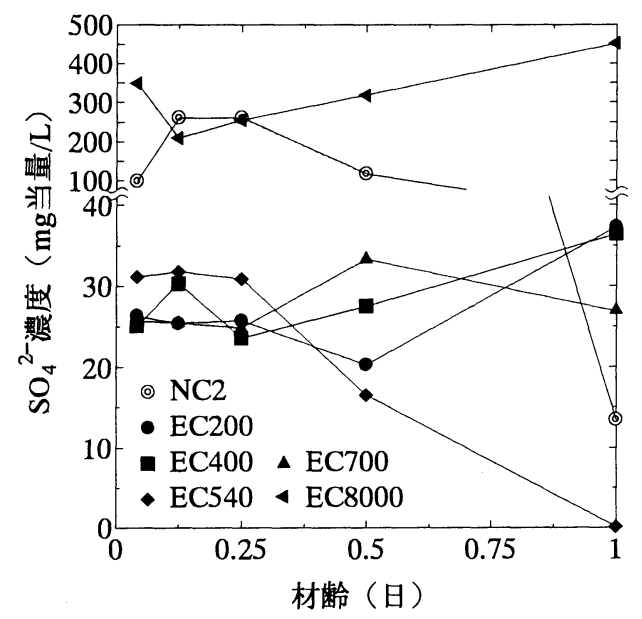

図-4 細孔溶液中の $\mathrm{SO}_{4}{ }^{2-}$ 濃度の経時変化（材齡 1 日まで）

\section{（2）細孔溶液中の硫酸イオンの挙動}

$\mathrm{W} / \mathrm{C}=0.50$ で作製した供試体について，細孔溶液中の $\mathrm{SO}_{4}^{2}$-濃度の経時変化を図-3に, 材龄 1 日までの結果を拡 大したものを図 4 に示す.

表-1 に示す化学組成と図-4 に示す結果を比較したと き, $\mathrm{SO}_{4}{ }^{2}$ の溶出は $\mathrm{NC}$ に比べて $\mathrm{EC}$ の方が遅いことがわ かる. いずれのセメントにおいても，添加された石こう は一水石こうと半水石こうの形態で存在しているが, NC の方が溶解性の高い半水石こうとして存在する量が多い ことを示唆しているものと考えられる. また，低塩素型 $\mathrm{EC}$ と $\mathrm{NC}$ のいずれも長期的には $\mathrm{SO}_{4}^{2}$-濃度が低下してお り，エトリンガイトが生成されていることがわかるが, 濃度の低下する時期が異なる. 細孔溶液組成の経時変化 に関する結果のみでは判断できないが, EC では材跲 1 日程度までエトリンガイトの生成が進行しつつ徐々に $\mathrm{SO}_{4}^{2}$-の溶出が継続していることが予想される. ただし, $\mathrm{EC} 540$ では材齢初期から 1 日までの間に Cl濃度と $\mathrm{SO}_{4}{ }^{2-}$ 濃度のいずれも急激に減少しており, $\mathrm{C}_{3} \mathrm{~A}$ とともに $\mathrm{C}_{4} \mathrm{AF}$ の含有量か高くなっていることが，この結果に影響して いるものと思われる.

材龄 28 日では, 低塩素型 EC と NC のいずれにおいて も $\mathrm{SO}_{4}^{2}$-濃度に大きな相違は見られない。

\section{（3）細孔溶液中の水酸化物イオン濃度の変化}

$\mathrm{W} / \mathrm{C}=0.50$ で作製した供試体について, 細孔溶液中の $\mathrm{OH}$ 濃度の経時変化を図-5に，材齢 1 日までの結果を拡 大したものを図-6に示す.

材制令 1 日までの低塩素型 ECでは，塩素含有量に関係 なくほぼ同じ值を示しており, NC の半分程度となって いる. また, NCでは材齢 1 日以降濃度が上昇している のに対して, 低塩素型ECでは EC540を除いてほとんど 


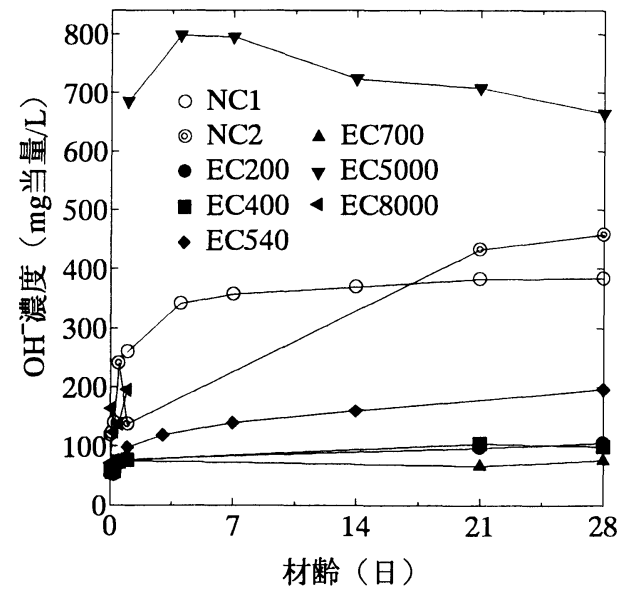

図-5 細孔溶液中の $\mathrm{OH}$ 濃度の経時変化

変化が見られない，低塩素型 EC と NCのアルカリ含有 量の相違を反映した結果と思われる.

一方, 高塩素型ECでは, EC8000 で混練後 1 時間にお ける OH濃度は NC よりも低いが，材齢 1 日以降では EC5000において NCの倍程度の值を示している. セメン 卜中の $\mathrm{SO}_{3}$ はアルカリの中でも特にカリウム之選択的に 反応してアルカリ硫酸塩を形成する ${ }^{10)}$. そのため, セメ ント中の水溶性アルカリは $\mathrm{Na}_{2} \mathrm{O}$ よりも $\mathrm{K}_{2} \mathrm{O}$ に由来して いる比率が高いわ. したがって, 極初期における細孔溶 液中の $\mathrm{OH}$ 濃度の上昇は, カルシウムとともにカリウム に依存する割合が高くなるが, 高塩素型 EC では概して $\mathrm{K}_{2} \mathrm{O}$ の含有量がNCと比較して少ないため, 極初期の $\mathrm{OH}$ 濃度の上昇が遅延しているものと思われる. 一方, 長期 材㱓でみたとき, EC5000 のアルカリ含有量がNCよりも 高くなっていることがOH濃度を高くしている一因と思 われるが，それとともにフリーデル氏塩の生成量が NC よりも多くなるため, 式(1)の反応により $\mathrm{OH}$ がより多く 生成されることも $\mathrm{OH}$ 濃度を高くしている原因ではない かと考えられる.

$$
\begin{aligned}
& \mathrm{C}_{3} \mathrm{~A}+\mathrm{Ca}(\mathrm{OH})_{2}+10 \mathrm{H}_{2} \mathrm{O}+2 \mathrm{Cl}^{-} \\
& \rightarrow \mathrm{C}_{3} \mathrm{~A} \cdot \mathrm{CaCl}_{2} \cdot 10 \mathrm{H}_{2} \mathrm{O}+2 \mathrm{OH}^{-}
\end{aligned}
$$

Gouda $^{18)}$ や Hausmann ${ }^{19}$ は, アルカリ水溶液中の軟鋼が 腐食し始める限界状態は[Cly[OH]で表現できるとの実 験結果を示し, 以降, 鉄筋腐食との関連において細孔溶 液中の $\left[\mathrm{Cl}^{-} y[\mathrm{OH}]\right.$ に着目した研究が行われているが, 腐 食を引き起こすとされる $[\mathrm{Cl} y[\mathrm{OH}]$ の值は研究者によっ て異なっている. Gouda の実験によれば 0.3〜0.4, Hausmann の実験によれば 0.6 1.0 となっており, 米澤ら の実験 ${ }^{20)} て ゙ は$ 約 5 という值を示している. 米澤らが指摘

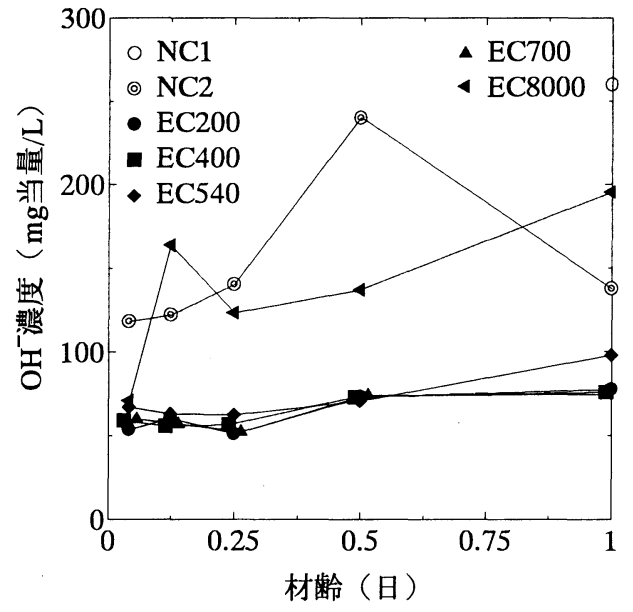

図-6 細孔溶液中の $\mathrm{OH}$ 濃度の経時変化（材澮 1 日まで）

しているように ${ }^{20)}$, 腐食を引き起こす $\left[\mathrm{Cl}^{2} y[\mathrm{OH}]\right.$ の限界 值は，鋼の表面状態や成分あるいは熱処理等によって大 きく変化しうるものであり, 上記の值は水溶液中に浸漬 した鋼による結果であるが, コンクリート中ではコンク リートとの付着の良否によっても当然相違することとな る. しかし, $[\mathrm{Cl}][\mathrm{OH}] て ゙$ 示される值が鉄筋腐食を引き 起こす状態を考える指標として有効であることは否めな いものと思われる.

本研究において, 図-1, 図-2ならびに図-5, 図-6で得 られた結果を用いて, $\mathrm{w} / \mathrm{C}=0.50$ で作製した供試体につい て細孔溶液中の $[\mathrm{Cl} y[\mathrm{OH}]$ を計算した結果を図-7に，材 齢 1 日までを拡大したものを図-8に示す.

EC8000では材齢初期に[Cly[OH] $]$ が比較的大きな值を 示しているが，それ以外の ECではいずれの材龄におい ても腐食の限界とされる値を下回っている. 特に低塩素 型ECでは, NCよりも高いものの, 腐食の限界とされる 値は大きく下回っている. 図-9 は, 試薬の $\mathrm{NaCl} と \mathrm{NaOH}$ を用いて表-3に示す溶液を調製し，その溶液中への鉄筋 の浸漬, 大気中への暴露をそれぞれ 24 時間ずつ行い, こ れを 8 週間続けたときの鉄筋の腐食減量を示したもので ある ${ }^{21)}$. 図-9に示すように, $[\mathrm{Cl} y[\mathrm{OH}]$ が 0.01 前後のと きには NCを用いたセメントペーストの場合の結果とほ とんと変わりがなく, NC を用いたセメントペーストで 外部から海水が浸入することを模した場合の方か腐食は より発生しやすいことがわかる.

これらのことから, 特に低塩素型ECの場合には, EC を用いるがために腐食か㴧念されることは考え難く, 鉄 筋コンクリートにおいても NC と同様に使用が可能であ り, 外部から塩分が容易に浸透しないよう緻密なコンク リートとすることの方が重要であると考えられる. 
表-3 鉄筋腐食のシミュレーションに用いた溶液の種類

\begin{tabular}{|c|c|c|c|c|}
\hline 番号 & $\begin{array}{c}\mathrm{Cl}^{-} \text {濃度 } \\
(\mathrm{mg} \text { 等量/L) }\end{array}$ & $\begin{array}{c}\mathrm{OH}^{-} \text {濃度 } \\
(\mathrm{mg} \text { 等量 } \mathrm{L})\end{array}$ & {$\left[\mathrm{Cl}^{-}\right] /\left[\mathrm{OH}^{-}\right]$} & 備 考 \\
\hline 1 & 500 & 530 & 0.94 & $\begin{array}{l}{[\mathrm{Cl}] \text { ]海水中の塩化物イオン濃度, }[\mathrm{OH}] \text { は NC3 を用いたセメン }} \\
\text { トペーストの材齢 } 28 \text { 日におけ濃度に調整 }\end{array}$ \\
\hline 2 & 50 & 5,000 & 0.01 & {$\left[\mathrm{Cl}^{-}\right] /\left[\mathrm{OH}^{-}\right]=0.01$ とし, $\mathrm{Cl}^{-}$濃度を高めに設定 } \\
\hline 3 & 5 & 500 & 0.01 & {$\left[\mathrm{Cl}^{-}\right] /[\mathrm{OH}]=0.01$ とし, $\mathrm{Cl}^{-}$濃度を低めに設定 } \\
\hline 4 & 2.6 & 360 & 0.0072 & $\begin{array}{l}\text { 塩素含有量約 } 0.1 \% の \text { EC を用いたセメントペーストの材齢 } 28 \text { 日 } \\
\text { 細孔溶液組成に相当 }{ }^{21)}\end{array}$ \\
\hline 5 & 0.65 & 220 & 0.003 & E540を用いたセメントペーストの材柃 28 日細孔溶液組成に相当 \\
\hline 6 & 0.15 & 530 & 0.0003 & NC3を用いたセメントペーストの材柃 28 日細孔溶液組成に相当 \\
\hline
\end{tabular}

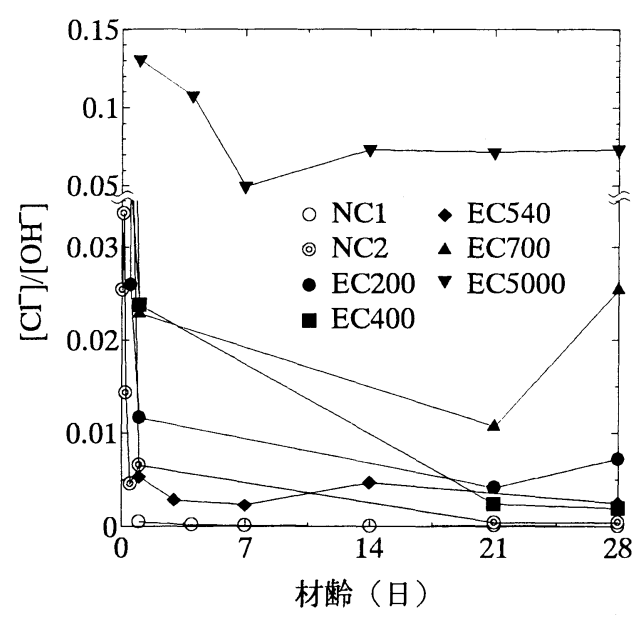

図-7 細孔溶液中の[C] $][\mathrm{OH}]$ の経時変化

\section{（4）細孔溶液中の陽イオン濃度の変化}

$\mathrm{W} / \mathrm{C}=0.50$ で作製した供試体について, 細孔溶液中の $\mathrm{Na}^{+}$濃度, $\mathrm{K}^{+}$濃度, $\mathrm{Ca}^{2+}$ 濃度の経時変化をそれぞれ図-10, 図-12，図-14に，材龄 1 日までの結果を拡大したものを それぞれ図-11, 図-13, 図-15に示す.

表-1に示されるように，低塩素型 EC は NC と比較し てアルカリ含有量が低く, 特に $\mathrm{K}_{2} \mathrm{O}$ の含有量は低塩素型 EC, 高塩素型EC ともに著しく低い. 図-10～図-13 の結 果はそれらを反映したものとなっているが，概して EC における細孔溶液中へのアルカリの溶出が $\mathrm{NC}$ と比較し て遅くなっている，低塩素型 $\mathrm{EC} に$ 含まれる $\mathrm{Na}_{2} \mathrm{O}$ 量は $\mathrm{NC}$ と同オーダーであるにもかかわらず材齢 1 日におけ る $\mathrm{Na}^{+}$の溶出量は EC540を除いて NCの約 $1 / 10$, 低塩素 型 $\mathrm{EC}$ の $\mathrm{K}_{2} \mathrm{O}$ 量は $\mathrm{NC}$ の 1/20 1/10 であるが $\mathrm{K}^{+}$の溶出量 はEC540を除いて約 $1 / 100$ となっている. 前述した $\mathrm{SO}_{4}^{2-}$ 濃度の結果と合わせて考えたとき, 低塩素型 EC ではア ルカリ硫酸塩として存在しているアルカリが NC と比較 して少なく, カルシウムシリケート相やカルシウムアル ミネート相に固溶して存在していることか摊察される.

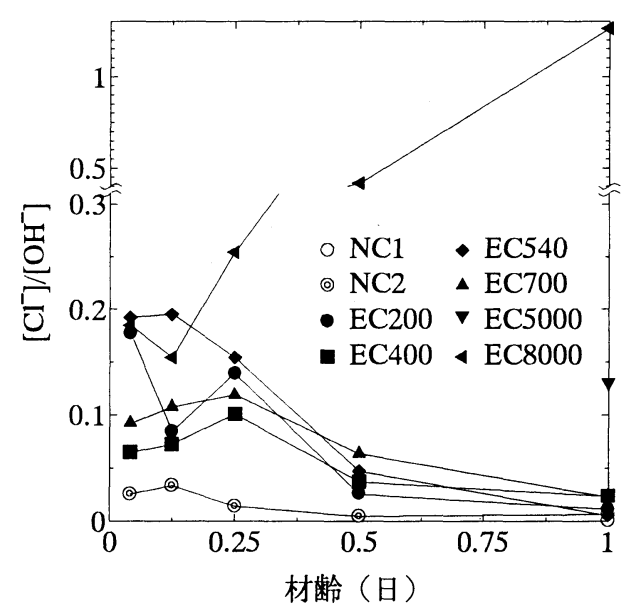

図-8 細孔溶液中の $\left[\mathrm{Cl}^{-}\right] /\left[\mathrm{OH}^{-}\right]$の経時変化（材齢 1 日まで）

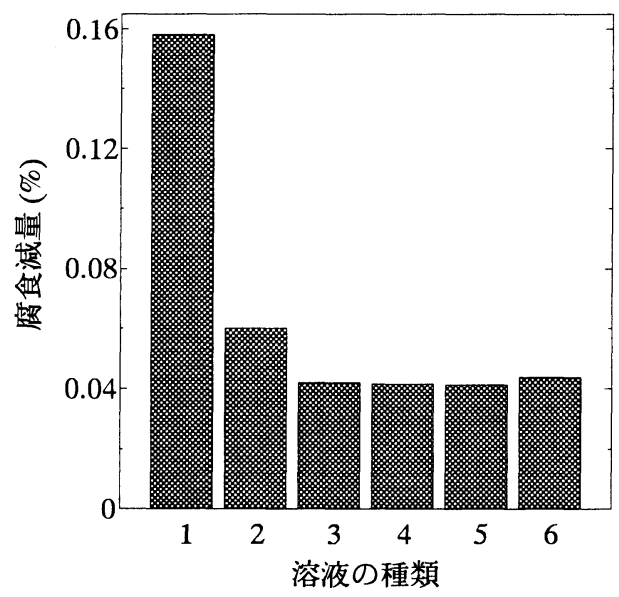

図-9 表-3 に示す種類の溶液を用いて行った鉄筋腐食シミュレ ーションによる鉄筋の腐食減量

極初期材齢における $\mathrm{Ca}^{2+}$ 濃度は $\mathrm{NC}$ と $\mathrm{EC}$ との間に大 きな相違はみられない，ただし，材齢 3 時間以降 NCで 


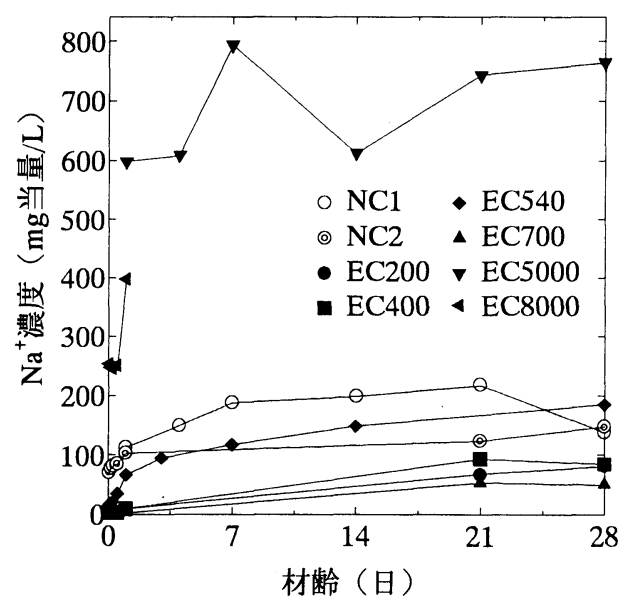

図-10 細孔溶液中の $\mathrm{Na}^{+}$濃度の経時変化

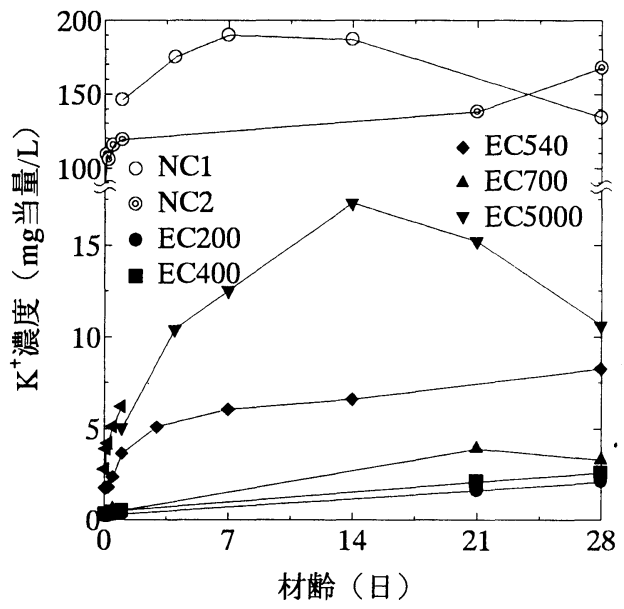

図-12 細孔溶液中の $\mathrm{K}^{+}$濃度の経時変化

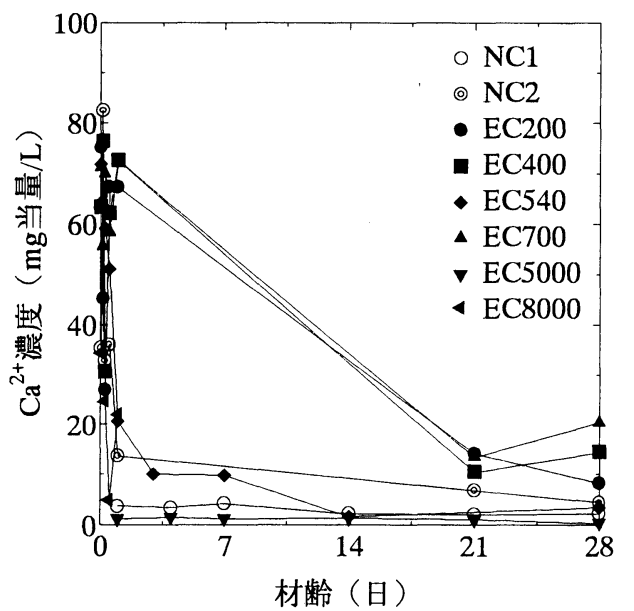

図-14 細孔溶液中の $\mathrm{Ca}^{2+}$ 濃度の経時変化

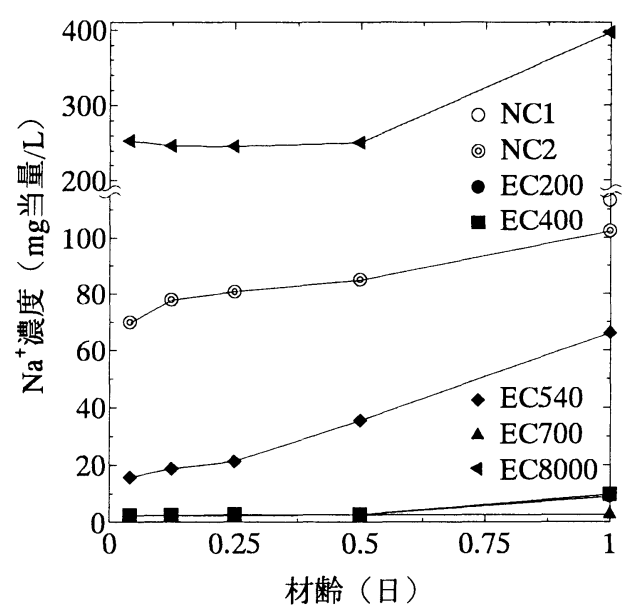

図-11 細孔溶液中の $\mathrm{Na}^{+}$濃度の経時変化（材齢 1 日まで）

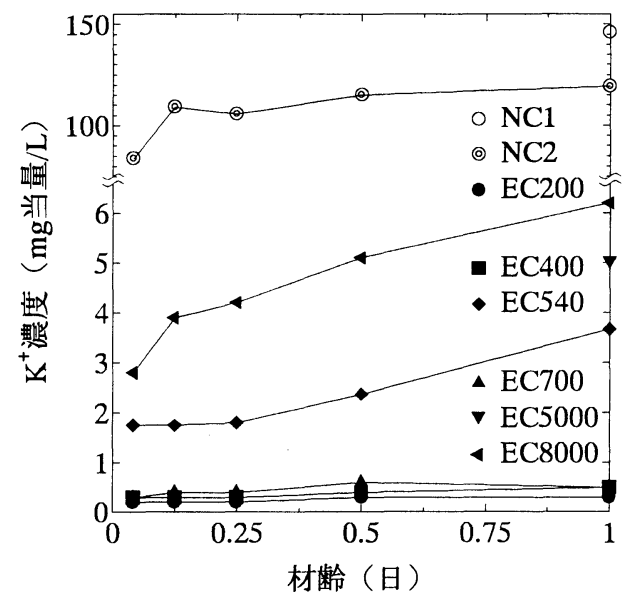

図-13 細孔溶液中の $\mathrm{K}^{+}$濃度の経時変化（材柃 1 日まで）

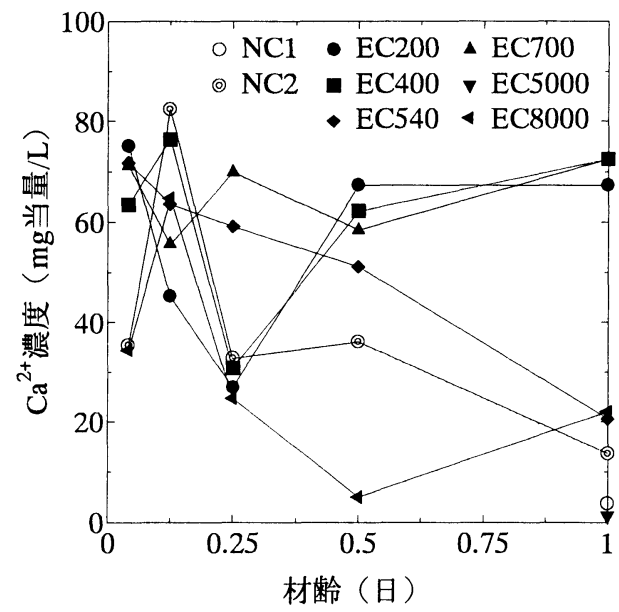

図-15 細孔溶液中の $\mathrm{Ca}^{2+}$ 濃度の経時変化（材齢 1 日まで） 


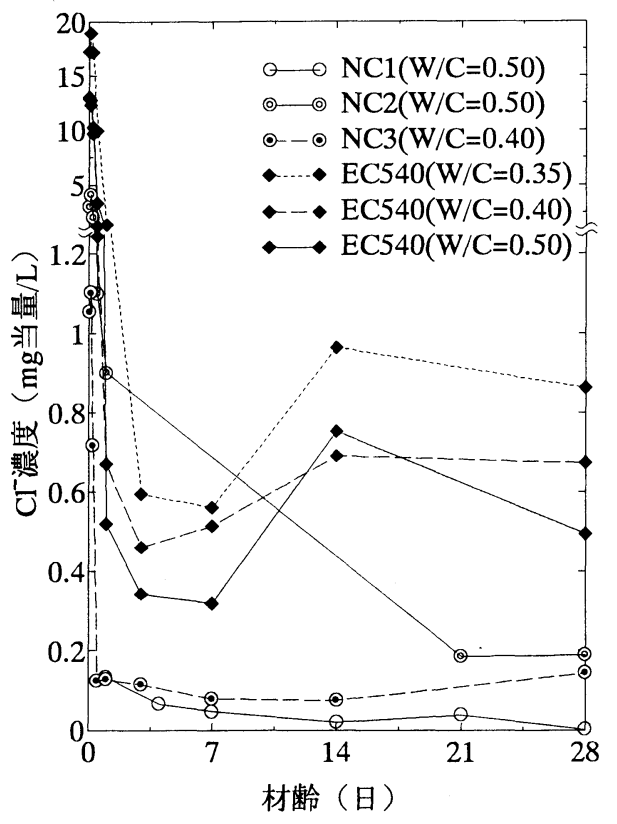

図-16 水セメント比の異なるセメント硬化体細孔溶液中の $\mathrm{d}$ 濃度の経時変化

は徐々に $\mathrm{Ca}^{2+}$ 濃度が低下しているのに対して，EC540を 除く低塩素型 EC では材秢 1 日までほぼ一定の值で推移 している. 材齢初期における細孔溶液中では， $\mathrm{CaSO}_{4}$ あ るいは $\mathrm{Ca}\left(\mathrm{OH}_{2}\right.$ が飽和状態または過飽和状態となってい るため, $\mathrm{Ca}^{2+}$ の溶出は $\mathrm{CaSO}_{4}$ や $\mathrm{Ca}\left(\mathrm{OH}_{2}\right.$ の溶解度によっ て左右されてくるものと思われる. 図-4に示されるよう に, NC や EC540 ではエトリンガイトの生成に伴って $\mathrm{SO}_{4}^{2}$-濃度が徐々に低下し, EC540を除く低塩素型 ECで は $\mathrm{SO}_{4}^{2}$-濃度がほとんと変化していない.この傾向は $\mathrm{Ca}^{2+}$ 濃度の変化と比較的一致している. 一方, 図-6に示した $\mathrm{OH}$ 濃度の結果と比較したとき, $\mathrm{OH}$ 濃度は全体的にや や上昇の傾向にある. 式(1)で示したように, フリーデル 氏塩の生成に伴う $\mathrm{OH}$ 解離に起因していることが考え られるが，その影響は細孔溶液中の $\mathrm{Ca}^{2+}$ 濃度を変化させ るには至っていない. $\mathrm{Ca}^{2+}$ 濃度は $\mathrm{OH}$ 濃度よりも $\mathrm{SO}_{4}^{2-}$ 濃度の変化の影響を大きく受けていることとなる.

\section{（5）水セメント比が細孔溶液組成に及ぼす影響}

EC5 40 を用い，W/C $=0.35 ， 0.40 ， 0.50$ で作製した供試 体について, 細孔溶液中のCl濃度の経時変化を図-16に, 材㱓 1 日までの結果を拡大したものを図-17にそれぞれ 比較用として使用した NC と合わせて示す.

材歯 1 日まででは, $\mathrm{W} / \mathrm{C}=0.40$ と $\mathrm{W} / \mathrm{C}=0.50$ の供試体で Cl濃度に大きな差がみられないが, 長期材龄では水セメ ント比か低いほど C濃度が高くなっている.いま, 密封 養生を行っていることから水分の逸散はないものとして，

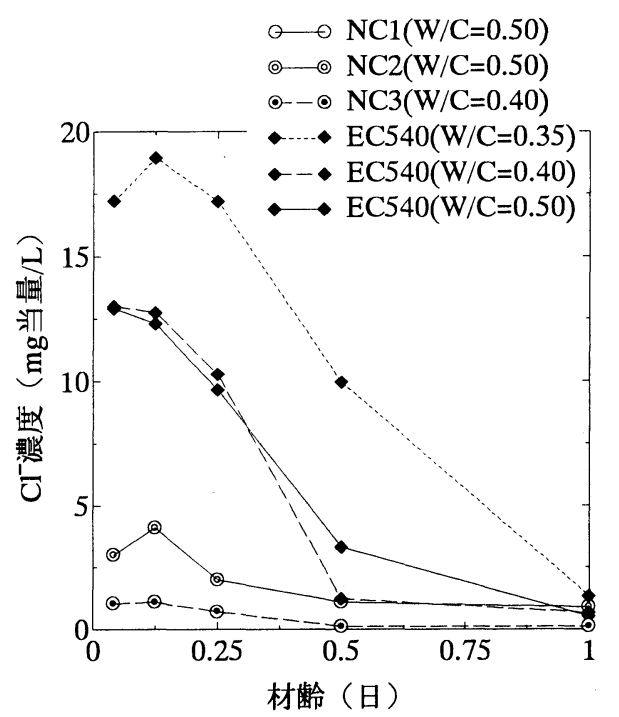

図-17 水セメント比の異なるセメント硬化体細孔溶液中の $\mathrm{C}$ 濃度の経時変化（材粭 1 日まで）

配合比から $\mathrm{W} / \mathrm{C}=0.35 ， 0.40$ ならびに 0.50 の硬化体中に 存在する単位容積あたりの水分量の比率を計算すると, およそ 1:1.06:1.16 となる. ここで, 材龄 28 日の時点でセ メント質量の $20 \%$ に相当する水分が水和に消費されたと すると, 残りの水分量の比率はおよそ 1:1.24:1.63 となる. この比率の逆数はおよそ 1:0.81:0.61 となるが, 材齢 28 日における $\mathrm{W} / \mathrm{C}=0.35,0.40$ ならびに 0.50 の Cl濃度の比 率を計算すると，およそ 1:0.78:0.57 となり，上記の比率 とほぼ一致する.すなおち, 細孔溶液中に存在する $\mathrm{Cl}^{-}$ の量は水セメント比に関わらずほぼ一定で, 水セメント 比の相違力浠釈の程度の相違となっていることか推察さ れる.一般に水セメント比が高いほど水和速度が大きく なることから, 若材㱓における水和が $\mathrm{W} / \mathrm{C}=0.40$ よりも $\mathrm{W} / \mathrm{C}=0.50$ の方が早く進行したために水分の消費量が相 対的に後者の方が多くなり，その結果として細孔溶液中 の見かけの Cr濃度が高くなったために W/C=0.40 と $\mathrm{W} / \mathrm{C}=0.50$ の Cl濃度がほぼ同じ值て推移したのではない かと考えられる.

\section{（6）細孔溶液組成からみた鉄筋腐食の可能性}

以上の結果で示されるように, EC を用いたセメント 硬化体の細孔溶液中の Cl濃度は, NC と比較して高くは なるものの, 特に低塩素型 ECにおいては含有量の相違 ほどには顕著な濃度の上昇となっていない，また，十分 な OH濃度の供給があることから，鉄筋腐食の指標と考 えられる[Cl-y[OH]も大きな值とはなっていない，高塩 素型ECに関しては, 材秢初期に[Cly[OH] $]$ が 1 を超える ところまで達するものの, 水和反応が極めて速やかに進 行するために細孔溶液の減少が早く, 細孔溶液の連続性 
が保たれにくい状態となっている. 本研究の範囲におい て，細孔溶液組成ならびに細孔溶液の連続性の観点から 得られたこれらの結果を総合して勘案したとき，EC を 用いたセメント硬化体により鉄筋腐食が生じる可能性は, $\mathrm{NC}$ の場合と大きく異ならないものと判断される.ただ し，この点に関しては，硬化体の緻密さの観点からさら に詳細な検討を要するとともに，先述のように，鉄筋コ ンクリートにおいて外部から塩分が容易に浸透しないよ う緻密なコンクリートとすることの方が重要であると考 えられる。

\section{4. 結論}

本研究は，都市ごみ焼却灰を原料の約 50\%に使用して 製造されたセメント ECについて，セメントのカルシウ ムアルミネートや塩素の含有量か高いことか鉄筋腐食に 及ぼす影響を，セメント硬化体に含まれる細孔溶液組成 に着目して検討を行ったものである. 塩素含有量が 0.02\% 0.07\%と比較的低い低塩素型 ECならびに塩素含 有量が 0.5\% 0.8\%と比較的高い高塩素型 ECについて, 普通ポルトランドセメント $\mathrm{NC}$ と比較して実験を行い， 以下の結論が得られた。

（1）特に低塩素型 EC の場合には，細孔溶液組成の観点 からは EC を用いるがために腐食か瀗念されること は考え難く，鉄筋コンクリートにおいても NC 之同 様に使用が可能であり, 外部から塩分が容易に浸透 しないよう緻密なコンクリートとすることの方が重 要である.

(2) 低塩素型 EC では NC と同様に, 材龄の経過に伴っ て細孔溶液中の Cl濃度が低下するが, 高塩素型 $\mathrm{EC}$ では材齢の経過に伴う変化が見られない．

(3) 低塩素型ECを用いた場合の細孔溶液中における Cl 濃度は, NC と比較して高くなるが, ECと NCの塩素含有 量の差ほどの相違とはならない，ECにおける固定可能 な塩素量が NCよりも多くなっていることか推察さ れた.

（4）細孔溶液中の $\mathrm{SO}_{4}^{2}$ 濃度は, 低塩素型 $\mathrm{EC}$ と NCにお いていずれも長期的には低下するが，その傾向は異 なり，セメント中に存在する石こう等硫酸塩の存在 形態の相違を反映している. また, $\mathrm{SO}_{4}^{2}$-濃度の経時 変化はほぼ $\mathrm{Ca}^{2+}$ 濃度の経時変化之一致する.

(5) 細孔溶液中の $\mathrm{OH}$ 濃度は，セメント中のアルカリ含 有量の相違を反映した結果となる. また，概して EC における細孔溶液中へのアルカリの溶出が $\mathrm{NC}$ と比 較して遅くなる.
謝辞 : 本研究の一部は, 科学研究費補助金基盤研究 (C) 一般 (平成 12 年度 13 年度, 課題番号 12650461), 第 14 回 (2000 年度) セメント協会研究奖励金により行われ たものである. また，原子吸光光度法，フレーム光度法 ならびにイオンクロマトグラフィーによる分析にあたっ ては，東京大学生産技術研究所魚本研究室のご協力をい ただいた。ここに記して深甚の謝意を表する。

\section{参考文献}

1) 友澤史紀、野口貴文，横田紀男，本田優，高橋茂：完全リ サイクルコンクリート（エココンクリート）の研究，日本 建築学会大会学術講演梗概集 A。pp.341-342、1994 年9月.

2) 河井徹，渡辺守成，長瀧重義：コンクリートの再利用例— 解体骨材を用いたプレパックドコンクリート工法，コン クリート工学, Vol.29, No.7, pp.91-95，1991 年7月.

3) 山本達: ガラスカレットの骨材への利用, コンクリートエ 学, Vol.34, No.7, pp.106-107, 1996年7月.

4) 土木学会コンクリート委員会コンクリート資源有効利用 小委員会:コンクリートライブラリー 96 資源有効利用の現 状之課題，pp.89-140，1999年10月 25 日.

5) 日刊工業新聞 1995 年 8 月 1 日付記事より.

6) 山崎之典, 石井準一郎，高橋良文，大同均 : 下水污泥の七 メント原料への有効利用，第 48 回セメント技術大会講演 集, pp.86-91， 1994.

7) 財団法人クリーン・ジャパン・センター: 都市型総合廃棄 物利用エコセメント生産技術 実証訌験結果報告書, 1997 年9月 10 日.

8) 小野義徳 大森啓至，田熊靖久: 都市ゴミ焼却灰から製造 されるエコセメント, セメント・コンクリート, No.586, pp.1-8，1995 年 12 月.

9) 内川浩, 尾花博 : 都市型総合廃裹物を原料とする環境共存 型セメントーエコセメントー, コンクリート工学, Vol.34, No.4, pp.57-63，1996年4月.

10）上野直樹，原田宏，須藤勘三郎 : 塩素バイパスシステムに よるセメントキルンの安定運転と廃菓物の有効利用, セメ ント・コンクリート, No.634, pp.28-35，1999年 12 月.

11) TR R 0002 エコセメント，財団法人日本規格協会，2000年 5 月 31 日.

12) Longuet, $\mathrm{P}$., Burglen, $\mathrm{L}$ and Zelwer, A. : La phase liquide du ciment hydraté, Revue des Matériaux de Construction et de Travaux, 676, pp.35-41, 1973.

13) Bameyback, R.S. Jr. and Diamond, S. : Expression and analysis of pore fluids from hardened cement pastes and mortars, Cement and Concrete Research, Vol.11, No.2, pp.279-285, 1981.

14）萩野千晶 : カルシウムアルミネート系セメントの基䃈的性 状, 広島大学修士論文, p.62, 1997.

15) 田澤栄一，河合研至，小野義徳: 都市廃裹物を利用した力 ルシウムクロロアルミネート系セメントの性質, セメン 
ト・コンクリート論文集, No.51, pp.696-701, 1997.

16) Jawed, I. and Skalny, J. : Alkalis in cement : A review, I. Forms of alkalis and their effect on clinker formation, Cement and Concrete Research, Vol.7, No.6, pp.719-730, 1977.

17) 河合研至小林一輔 : セメント中の水溶性アルカリ量 土 木学会論文集, No.433/V-15, pp.35-39，1991 年 8 月.

18) Gouda, V.K. : Corrosion and corrosion inhibition of reinforcing steel: I. Immersed in alkaline solution, British Corrosion Journal, Vol.5, pp.198-203, Sep 1970.

19) Hausmann, D.A : Steel corrosion in concrete, Materials Protection, Vol.6, pp.19-23, Nov 1967.
20) 米澤敏男, Ashworth, V., Procter, R.P.M. : コンクリート中の 鋼材腐食における塩素イオンの限界量について, 第 8 回コ ンクリート工学年次講演会論文集, pp.141-144, 1986.

21) 河合研至, 田澤榮一, 松本健一, 横山湤: 都市型廃棄物を 利用したセメント水和物の塩素挙動, セメント・コンクリ 一ト論文集, No.54, pp.502-507, 2000.

\section{PORE SOLUTION COMPOSITION OF HARDENED CEMENT PASTE MADE FROM MUNICIPAL SOLID WASTES}

\section{Kenji KAWAI, Ken-ichi MATSUMOTO, Ei-ichi TAZAWA and Shigeru YOKOYAMA}

Cement manufactured from municipal solid wastes has been developed. About 50\% of raw materials for this œment are wastes. This cement contains a larger amount of $\mathrm{C}_{3} \mathrm{~A}$ and chlorine than normal portland cement. Therefore steel corrosion is worried about when this cement is used for reinforced concrete. In this study, the possibility of steel corrosion for this cement is investigated in terms of pore solution composition and its changes. As a result, although the chloride ion concentration of pore solution for this cement is higher than for normal portland cement, the ratio of the chloride ion concentration relative to the hydroxide ion concentration is low. In addition, the amount of chloride accommodated by cement hydrates is high because of high $\mathrm{C}_{3} \mathrm{~A}$ content. It is concluded that the possibility of steel corrosion for this cement is as well as for normal portland cement. 